\title{
Does economic freedom fosters banks' performance? panel evidence from Malaysia
}

\begin{abstract}
The present paper provides new empirical evidence on the impact of economic freedom on banksô performance. The empirical analysis is confined to the Malaysian banking sector during the period of 1999ï 2007. We find that overall economic freedom and business freedom exerts positive impacts, implying that higher (lower) freedom on the activities that banks can undertake and entrepreneurs to start businesses increases (reduces) banksô profitability. The empirical findings seem to suggest that corruption has a corrosive impact on Malaysian banksô profitability. Interestingly, the impact of monetary freedom is negative, demonstrating the importance of government intervention in determining the profitability of banks operating in the Malaysian banking sector.
\end{abstract}

Keyword: Banks; Economic freedom; Profitability; Panel regression analysis; Malaysia 